\title{
The Effects of Recreational and Sportive Activities on the Quality of Life of Mothers with Autistic Children's
}

\author{
Hulusi Alp \\ Correspondence: Hulusi Alp, Faculty of Sport Sciences, Süleyman Demirel University, Isparta, Turkey.
}

Received: June 18, 2019

Accepted: July 22, 2019

Online Published: July 24, 2019

doi:10.11114/jets.v7i8.4401

URL: https://doi.org/10.11114/jets.v7i8.4401

\begin{abstract}
The aim of this study was to determine the effects of recreational activities and sports on the quality of life of the mothers of autistic children. The population of this study is the mothers of autistic children living in Isparta. A total of twenty (20) mothers were chosen using random sampling method and split into control and application groups with equal number of samples (10). Mothers in the application group attended a fifteen (15) days program with 8 hours of specially planned activities per day. The activities consisted of nature walks, trips to historical and artistic sites and social tours (zoo, historical ruins, picnic etc.) as well as sportive activities (swimming). WHOQOL-BREF (TR) Quaility of Life Assessment Instrument was used as a pre-test before the study and as a post-test after the study for evaluating the results of the study. Results were analyzed using SPSS statistical analysis software. Mean rank differences of independent variables between groups and mean differences within groups were compared using a non-parametric test. The alpha level for Type 1 errors was $0.05(\alpha=0.05)$. The results revealed a statistically significant difference between the mothers of autistic children in the control and the application groups and the quality of life of the mothers in the application group increased $(p<0.05)$. There was no significant difference in quality of life of the mothers in the control group $(\mathrm{p}>0.05)$. Therefore, specially planned recreational and sportive activities improved the quality of life of the mothers with autistic children. The fact that no significant difference was observed in the control group can be due to the community of the mothers' daily workload.
\end{abstract}

Keywords: autisim, sportive activity, recreative activity, quality of life

\section{Introduction}

The term "autism" was first defined by child psychiatrist Leo Kanner in 1943 (Aydın \& Özgen, 2018). Autism or autism spectrum disorder is a complex developmental disability that is characterized by challenges with social skills, repetitive behaviors and difficulty in verbal and nonverbal communication (Harnois, 2016; DSM-V, autismspeaks.org, 2019; Greespan \& Wieder, 2017). Autism is a congenital problem which is usually noticed in the first two years of life and whose cause still remains unclear (Vural, 2007). Instead of a single reason, autism can be caused by interactions of multiple variables. Various problems in the nervous system that affects the structure or operation of the brain, or hundreds of genetic alterations can trigger this disorder. Behavioral variation in clinical findings shows us that environmental conditions are also effective (Kılıç Ekici, 2013). A lot of scientific studies agree that incidence of autism spectrum disorders is rapidly increasing. One in every sixty eight (68) children is diagnosed with autism around the globe. +While the exact numbers are unknown, it is estimated that 1.142 .568 individuals with autism and 4.568.000 family members that is affected by this situation are living in Turkey (Uz \& Kaya, 2018). When a new member enters the family changes in family relations occur. It also causes changes in expectations of spouses from each other, their occupations, immediate surroundings in short: every aspect of life. Additionally, having a disabled child, whatever that disability may be, brings a lot of challenges (Demir \& Keskin, 2018). Raising a child with autism is very difficult for the families. Most of the parents with children in autism spectrum disorder hope new treatments, programs and resources which can positively affect the quality of life of their children will be developed (Garrett, 2014). The fact that there isn't a 'cure' for autism causes despair in the families of children with autism, and higher levels of anxiety in mothers and fathers (McStay \& Trembath, 2014; Ciğerli et al., 2014). A lot of families with autistic children have concerns over not knowing what to do with the child or how will the child affect their lives (Top, 2009). On the other hand, economic burden of treatment and economic problems, exhaustion in parents caused by restricted social life, problems with other children in the family, fears of parents about neglecting their child, problems with education of autistic children, raising the child and problems related to it often come up (Çam \& Özkan, 2009). Psychological state 
of mothers and fathers affect their attitudes and social relations (Deveci \& Ahmetoğlu, 2018). Since mothers take most of the responsibility in caring of the child, aforementioned problems affect mothers more than fathers (Demir \& Keskin, 2018). Mothers can completely devote themselves to the disabled children and can neglect their spouses or other children, or even isolate themselves from any kind of social background (Ciğerli et al., 2014). Higher levels of anxiety in mothers of autistic children also affects their quality of life. The notion of family quality of life is derived from the term quality of life and is featured in health, psychology, socio-politics and lately inability (Meral \& Cavkaytar, 2014). It is observed that families with disabled children follow various adaptation strategies and this process is affected by a lot of variables. Helping the parents during this process and planning support programs will ease the adaptation. It is essential to know the feelings, needs, experiences and other factors affecting the parents for planning these support programs (As cited in, Genç, 2017). The goal of this study is to determine the effects of recreative and sportive activities on quality of life of mothers with autistic children.

\section{Method}

\subsection{Research Model and Purpose}

This research was based on a quantitative research approach and was designed in the pre-test post-test experiment model. Purpose of the experiment was to determine the effects of recreative and sportive activities on quality of life of mothers with autistic children.

\subsection{Research Group}

Mothers who are living in Isparta and have autistic children are the population of this research. Twenty (20) mothers were chosen using random sampling method and split into control and application groups with equal number of samples (10). Mothers in the application group attended a fifteen (15) days program with 8 hours of specially planned activities per day. The activities consisted of nature walks, trips to historical and artistic sites and social tours (zoo, historical ruins, picnic etc.) as well as sportive activities (swimming).

\subsection{Data Collection Tools}

WHOQOL-BREF (TR) Quality of Life Assessment Instrument was used as a pre and post-test for evaluation of the results. Eser et al. (1999) validates it and confirmed its reliability. There are long (WHOQOL-100) and short (WHOQOL-27) forms the test. The test access physical, psychological, social and environmental wellbeing and is composed of 26 questions. When Turkish version is used (27. question is the national question) environmental field score is called Environment-TR and Environment-TR field score is used as the environmental score.

Test-Retest Reliability: Correlation coefficients of the results of IWHOQOL-BREF (TR) tests applied to forty five (45) healthy college students with three weeks intervals on average varies between .57 and .81 .

Internal Consistency: Cronbach alpha values show that domains and facets of WHOQOL-BREF (TR) are highly consistent. For both sick and healthy individuals the highest consistency was observed in physical domain (.83 and .79$)$ and the lowest was observed in social domian (.53 for both groups) (Eser et al., 1999).

\subsection{Statistical Analysis of Data}

SPSS statistical analysis software was used for comparing pre and post test results. Wilcoxon test was used for comparing the dependent groups and Man-Whitney U test was used to compare the independent groups when the data is not normally distributed. The alpha level for Type 1 errors was $0.05(\alpha=0.05)$.

\section{Findings}

\section{Demographic Results}

Table 1. Percentage distribution of mothers in the research group.

\begin{tabular}{llc}
\hline Groups & N & Percentages \\
\hline Research group & 10 & 50 \\
Control group & 10 & 50 \\
Total & 20 & 100
\end{tabular}

Table 1 shows that $50 \%$ of the mothers in the research group are in the application group and the other $50 \%$ are in the control group. 
Table 2. Percentage distribution of genders in the research group

\begin{tabular}{lcc}
\hline Volunteer participant & Frequency & Percentages \\
\hline Female & 20 & 100 \\
\hline
\end{tabular}

Table 2 shows that $100 \%$ of the participants are female.

Table 3. Percentage distribution of ages in the research group

\begin{tabular}{lcc}
\hline & Frequency & Percentages \\
\hline $30-34$ & 9 & 45 \\
$35-40$ & 11 & 55 \\
Total & 20 & 100
\end{tabular}

Table 3 shows that $45 \%$ of the participants are in the 30-34 age group and 55\% are in the 35-40 age group.

Table 4. Percentage distribution of the education status of the participants

\begin{tabular}{lcc}
\hline & Frequency & Percentages \\
\hline High school & 20 & 100 \\
\hline
\end{tabular}

Table 4 shows that $100 \%$ of the participants are high-school graduates.

Table 5. Percentage distribution of the marital status of the participants

\begin{tabular}{lcc}
\hline & Frequency & Percentages \\
\hline Married & 15 & 75 \\
\hline Divorced & 5 & 25 \\
\hline Total & 20 & 100
\end{tabular}

Table 5 shows that $75 \%$ of the participants are married and the remaining $25 \%$ are divorced.

Table 6. Percentage distribution of the number of children that the participants have

\begin{tabular}{lcc}
\hline & Frequency & Percentages \\
\hline Single child & 5 & 25 \\
\hline Two children & 10 & 50 \\
\hline Three children & 5 & 25 \\
\hline Total & 20 & 100
\end{tabular}

Table 6 shows that $25 \%$ of the participants have a single child, $50 \%$ have two children and the remaining $25 \%$ have three children.

Table 7. Percentage distribution of the income status of research group

\begin{tabular}{lcc}
\hline & Frequency & Percentages \\
\hline Maintenance money & 5 & 25 \\
\hline Minimum wage & 15 & 75 \\
\hline Total & 20 & 100
\end{tabular}

Table 7 shows that $2 \overline{5 \% \text { of the participants receive a care assistance and } 75 \% \text { receive minimum wage }}$. 
Table 8. Results of the Mann Whitney U test of pre and post-test results on general quality of life and general health of the application and the control group

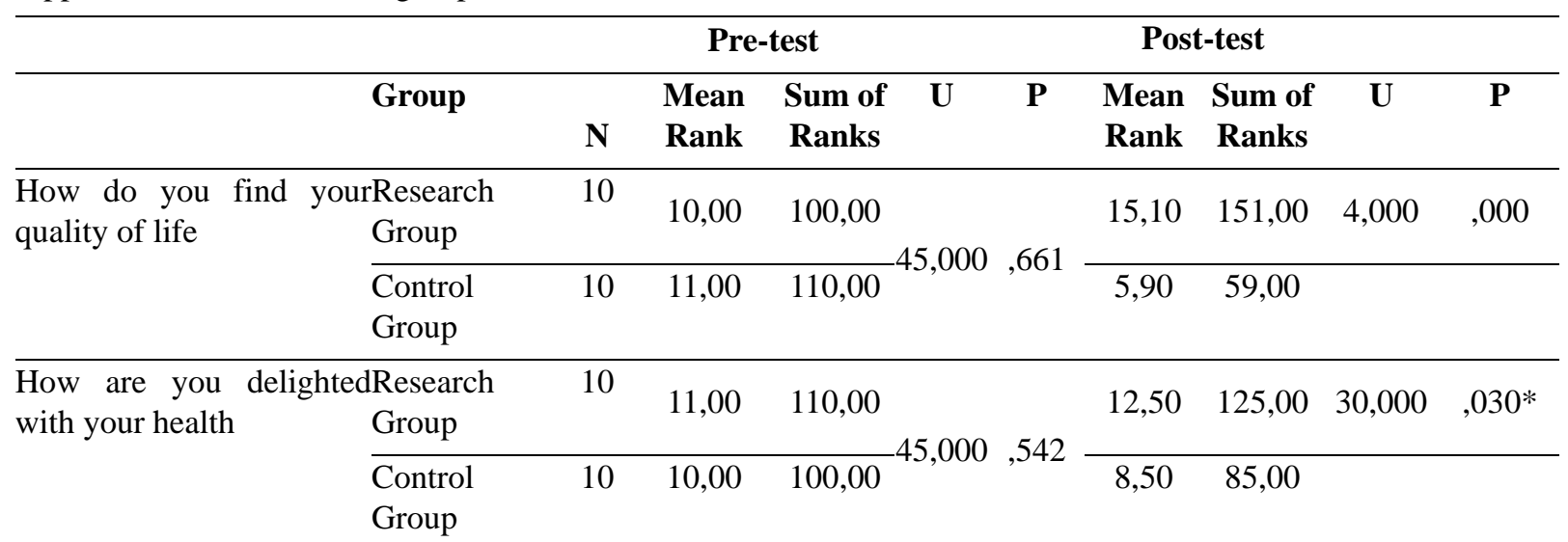

Table 8 shows that the application and the control groups did not differ significantly in pre-test results (U= 45.000, $\mathrm{p}>0.05)$, but showed a significant difference in post-test results $(\mathrm{U}=30.000, \mathrm{p}<0.05)$.

Table 9. Results of the Mann Whitney U test of pre and post-test results of the physical health domain of the application and the control group

\begin{tabular}{|c|c|c|c|c|c|c|c|c|c|}
\hline \multirow[b]{2}{*}{ Physical Domain } & \multirow[b]{2}{*}{$\mathbf{N}$} & \multicolumn{3}{|c|}{ Pre-test } & \multicolumn{5}{|c|}{ Post-test } \\
\hline & & $\begin{array}{l}\text { Mean } \\
\text { Rank }\end{array}$ & $\begin{array}{l}\text { Sum of } \\
\text { Ranks }\end{array}$ & $\mathbf{U}$ & $\mathbf{P}$ & $\begin{array}{l}\text { Mean } \\
\text { Rank }\end{array}$ & $\begin{array}{c}\text { Sum of } \\
\text { Ranks }\end{array}$ & $\mathbf{U}$ & $\mathbf{P}$ \\
\hline $\begin{array}{l}\text { To what extent do you feel thatResearch } \\
\text { physical pain prevents youGroup }\end{array}$ & 10 & 10,50 & 105,00 & \multirow{2}{*}{50,000} & \multirow{2}{*}{1,000} & 9,50 & 95,00 & \multirow{2}{*}{40,000} & \multirow{2}{*}{, 146 } \\
\hline $\begin{array}{l}\text { from doing what you need toControl } \\
\text { do }\end{array}$ & 10 & 10,50 & 105,00 & & & 11,50 & 115,00 & & \\
\hline \multirow{2}{*}{$\begin{array}{l}\text { How much do you need any } \\
\text { Research } \\
\text { medical treatment to function } \frac{\text { Group }}{\text { Control }} \\
\text { in your daily life } \\
\text { Group }\end{array}$} & 10 & 10,50 & 105,00 & \multirow{2}{*}{50,000} & \multirow{2}{*}{1,000} & 9,50 & 95,00 & \multirow{2}{*}{40,000} & \multirow[b]{2}{*}{, 146} \\
\hline & 10 & 10,50 & 105,00 & & & 11,50 & 115,00 & & \\
\hline $\begin{array}{l}\text { Research } \\
\text { Do you have enough energyGroup }\end{array}$ & 10 & 10,00 & 100,00 & \multirow{2}{*}{45,000} & \multirow{2}{*}{, 317} & 11,90 & 119,00 & \multirow{2}{*}{36,000} & \multirow{2}{*}{,088 } \\
\hline $\begin{array}{ll}\text { for everyday life } & \text { Control } \\
\text { Group }\end{array}$ & 10 & 11,00 & 110,00 & & & 9,10 & 91,00 & & \\
\hline \multirow{2}{*}{$\begin{array}{lc}\text { How well are you able to getGroup } \\
\text { around } & \text { Research } \\
& \text { Group }\end{array}$} & 10 & 10,50 & 105,00 & \multirow{2}{*}{50,000} & \multirow{2}{*}{1,000} & 15,50 & 155,00 & \multirow{2}{*}{, 000} & \multirow{2}{*}{, $000^{*}$} \\
\hline & 10 & 10,50 & 105,00 & & & 5,50 & 55,00 & & \\
\hline \multirow{2}{*}{$\begin{array}{l}\text { How satisfied are you } \\
\text { your sleep }\end{array}$} & 10 & 11,50 & 115,00 & \multirow{2}{*}{40,000} & \multirow{2}{*}{, 383} & 13,70 & 137,00 & \multirow{2}{*}{18,000} & \multirow{2}{*}{, $006^{*}$} \\
\hline & 10 & 9,50 & 95,00 & & & 7,30 & 73,00 & & \\
\hline \multirow{2}{*}{$\begin{array}{l}\text { How satisfied are you with } \begin{array}{l}\text { Research } \\
\text { your ability to perform your } \\
\text { daily living activities }\end{array} \\
\end{array}$} & 10 & 11,00 & 110,00 & \multirow{2}{*}{45,000} & \multirow{2}{*}{661} & 15,50 & 155,00 & \multirow{2}{*}{, 000} & \multirow{2}{*}{, $000^{*}$} \\
\hline & 10 & 10,00 & 100,00 & & & 5,50 & 55,00 & & \\
\hline \multirow{2}{*}{$\begin{array}{lc}\text { How satisfied are you } & \text { Research } \\
\text { your capacity for work } & \text { Controup } \\
& \text { Group } \\
\end{array}$} & 10 & 10,50 & 105,00 & \multirow{2}{*}{50,000} & \multirow{2}{*}{,739 } & 13,50 & 135,00 & 20000 & $007 *$ \\
\hline & 10 & 10,50 & 105,00 & & & 7,50 & 75,00 & 20,000 & , \\
\hline
\end{tabular}

Table 9 shows that there is no significant difference in physical domain pre-test scores between the control and the application group ( $p>0.05)$. However, post-test scores of the groups differ in sub-items: How well are you able to get around $(U=0.000, p<0.05)$, how satisfied are you with your sleep $(U=18.000, p<0.05)$, how satisfied are you with your ability to perform your daily activities $(\mathrm{U}=0.000, \mathrm{p}<0.05)$ and, how satisfied are you with your capacity to work $(\mathrm{U}=20.000, \mathrm{p}<0.05)$. 
Table 10. Result of the Mann Whitney U test of pre and post-test results of the psychological domain of the application and the control group

\begin{tabular}{|c|c|c|c|c|c|c|c|c|c|c|}
\hline \multirow[b]{2}{*}{ Psychological Domain } & \multirow[b]{2}{*}{ Group } & \multirow[b]{2}{*}{$\mathbf{N}$} & \multicolumn{3}{|c|}{ Pre-test } & \multicolumn{5}{|c|}{ Post-test } \\
\hline & & & $\begin{array}{l}\text { Mean } \\
\text { Rank }\end{array}$ & $\begin{array}{r}\text { Sum of } \\
\text { Ranks }\end{array}$ & $\mathbf{U}$ & $\mathbf{P}$ & $\begin{array}{l}\text { Mean } \\
\text { Rank }\end{array}$ & $\begin{array}{l}\text { Sum of } \\
\text { Ranks }\end{array}$ & $\mathbf{U}$ & $\mathbf{P}$ \\
\hline \multirow{2}{*}{$\begin{array}{l}\text { How much do you enjoy } \\
\text { life }\end{array}$} & $\begin{array}{l}\text { Research } \\
\text { Group }\end{array}$ & 10 & 10,00 & 100,00 & \multirow{2}{*}{45,000} & \multirow{2}{*}{, 542} & 15,10 & 151,00 & \multirow{2}{*}{4,000} & \multirow{2}{*}{, $000 *$} \\
\hline & $\begin{array}{l}\text { Control } \\
\text { Group }\end{array}$ & 10 & 11,00 & 110,00 & & & 5,90 & 59,00 & & \\
\hline \multirow{2}{*}{$\begin{array}{l}\text { To what extent do you } \\
\text { feel your life to be } \\
\text { meaningful }\end{array}$} & $\begin{array}{l}\text { Research } \\
\text { Group }\end{array}$ & 10 & 11,50 & 115,00 & \multirow{2}{*}{4,000} & \multirow{2}{*}{,383 } & 13,50 & 135,00 & \multirow{2}{*}{$-20,000$} & \multirow{2}{*}{, $004 *$} \\
\hline & $\begin{array}{l}\text { Control } \\
\text { Group }\end{array}$ & 10 & 9,50 & 95,00 & & & 7,50 & 75,00 & & \\
\hline \multirow{2}{*}{$\begin{array}{l}\text { How well are you able to } \\
\text { concentrate }\end{array}$} & $\begin{array}{l}\text { Research } \\
\text { Group }\end{array}$ & 10 & 11,50 & 115,00 & \multirow{2}{*}{40,000} & \multirow{2}{*}{,342 } & 13,50 & 135,00 & \multirow{2}{*}{20,000} & \multirow{2}{*}{, $004 *$} \\
\hline & $\begin{array}{l}\text { Control } \\
\text { Group }\end{array}$ & 10 & 9,50 & 95,00 & & & 7,50 & 75,00 & & \\
\hline \multirow{2}{*}{$\begin{array}{l}\text { Are you able to accept } \\
\text { your bodily appearance }\end{array}$} & $\begin{array}{l}\text { Research } \\
\text { t Group }\end{array}$ & 10 & 10,50 & 105,00 & \multirow{2}{*}{50,000} & \multirow{2}{*}{1,000} & 11,50 & 115,00 & \multirow{2}{*}{40,000} & \multirow{2}{*}{, 146} \\
\hline & $\begin{array}{l}\text { Control } \\
\text { Group }\end{array}$ & 10 & 10,50 & 105,00 & & & 9,50 & 95,00 & & \\
\hline \multirow{2}{*}{$\begin{array}{l}\text { How satisfied are you } \\
\text { with yourself }\end{array}$} & $\begin{array}{l}\text { Research } \\
\text { Group }\end{array}$ & 10 & 11,00 & 110,00 & \multirow{2}{*}{45,000} & \multirow{2}{*}{,648 } & 14,60 & 146,00 & \multirow{2}{*}{9,000} & \multirow{2}{*}{, $001 *$} \\
\hline & $\begin{array}{l}\text { Control } \\
\text { Group }\end{array}$ & 10 & 10,00 & 100,00 & & & 6,40 & 64,00 & & \\
\hline \multirow{2}{*}{$\begin{array}{l}\text { How often do you have } \\
\text { negative feelings such as } \\
\text { blue mood, despair, } \\
\text { anxiety, depression }\end{array}$} & $\begin{array}{l}\text { Research } \\
\text { Group }\end{array}$ & 10 & 8,40 & 84,00 & \multirow{2}{*}{30,000} & \multirow{2}{*}{, 123} & 10,50 & 105,00 & \multirow{2}{*}{50,000} & \multirow{2}{*}{1,000} \\
\hline & $\begin{array}{l}\text { Control } \\
\text { Group }\end{array}$ & 10 & 12,60 & 126,00 & & & 10,50 & 105,00 & & \\
\hline
\end{tabular}

Table 10 shows that there is no significant difference in psychological domain pre-test scores between the control and the application groups $(\mathrm{p}>0.05)$. Post-test scores of the groups differ in sub-items: How much do you enjoy life $(\mathrm{U}=0.000, \mathrm{p}<0.05)$, to what extent do you find your life meaningful $(\mathrm{U}=20.000, \mathrm{p}<0.05)$, how well are you able to concentrate $(U=20.000, p<0.05)$, how satisfied are you with yourself $(U=9.000, p<0.05)$.

Table 11. Result of the Mann Whitney $U$ test of pre and post-test results of the social relationships domain of the application and the control group

\begin{tabular}{|c|c|c|c|c|c|c|c|c|c|c|}
\hline & & & & Pre-test & & & & Post-test & & \\
\hline Social Domain & Group & $\mathbf{N}$ & $\begin{array}{l}\text { Mean } \\
\text { Rank }\end{array}$ & $\begin{array}{l}\text { Sum of } \\
\text { Ranks }\end{array}$ & $\mathbf{U}$ & $\mathbf{P}$ & $\begin{array}{l}\text { Mean } \\
\text { Rank } \\
\end{array}$ & $\begin{array}{l}\text { Sum of } \\
\text { Ranks }\end{array}$ & $\mathbf{U}$ & $\mathbf{P}$ \\
\hline \multirow{2}{*}{$\begin{array}{l}\text { How satisfied are you with your } \\
\text { personal relationships }\end{array}$} & $\begin{array}{l}\text { Research } \\
\text { Group }\end{array}$ & 10 & 12,00 & 120,00 & \multirow{2}{*}{35,000} & \multirow{2}{*}{,131 } & 15,50 & 155,00 & \multirow{2}{*}{,000 } & \multirow{2}{*}{, $000^{*}$} \\
\hline & $\begin{array}{l}\text { Control } \\
\text { Group }\end{array}$ & 10 & 9,00 & 90,00 & & & 5,50 & 55,00 & & \\
\hline \multirow{2}{*}{$\begin{array}{l}\text { How satisfied are you with your } \\
\text { sex life }\end{array}$} & $\begin{array}{l}\text { Research } \\
\text { Group }\end{array}$ & 10 & 13,00 & 130,00 & \multirow{2}{*}{35,000} & \multirow{2}{*}{,128 } & 13,00 & 130,00 & \multirow{2}{*}{35,000} & \multirow{2}{*}{,128 } \\
\hline & $\begin{array}{l}\text { Control } \\
\text { Group }\end{array}$ & 10 & 8,00 & 80,00 & & & 8,00 & 80,00 & & \\
\hline \multirow{2}{*}{$\begin{array}{l}\text { How satisfied are you with the } \\
\text { support you get from your } \\
\text { friends }\end{array}$} & $\begin{array}{l}\text { Research } \\
\text { Group }\end{array}$ & 10 & 10,50 & 105,00 & \multirow{2}{*}{50,000} & \multirow{2}{*}{1,000} & 15,50 & 155,00 & \multirow{2}{*}{,000 } & \multirow{2}{*}{, $000^{*}$} \\
\hline & $\begin{array}{l}\text { Control } \\
\text { Group }\end{array}$ & 10 & 10,50 & 105,00 & & & 5,50 & 55,00 & & \\
\hline
\end{tabular}


Table 11 shows that there is no significant difference in social relationships domain pre-test scores between the control and the application groups ( $p>0.05)$. Post-test scores of the groups differ in sub-items: How satisfied are you with your personal relationships $(\mathrm{U}=0.000, \mathrm{p}<0.05)$ and how satisfied are you with the support you get from your friends $(\mathrm{U}=0.000, \mathrm{p}<0.05)$.

Table 12. Result of the Mann Whitney U test of pre and post-test results of the environment domain of the application and the control group

\begin{tabular}{|c|c|c|c|c|c|c|c|c|c|c|}
\hline & & & & Pre-test & & & & Post-test & & \\
\hline Environment Domain & Group & $\mathbf{N}$ & $\begin{array}{l}\text { Mean } \\
\text { Rank }\end{array}$ & $\begin{array}{l}\text { Sum of } \\
\text { Ranks }\end{array}$ & $\mathbf{U}$ & $\mathbf{P}$ & $\begin{array}{l}\text { Mean } \\
\text { Rank }\end{array}$ & $\begin{array}{l}\text { Sum of } \\
\text { Ranks }\end{array}$ & $\mathbf{U}$ & $\mathbf{P}$ \\
\hline How safe do you feel in your & $\begin{array}{l}\text { Research } \\
\text { Group }\end{array}$ & 10 & 12,50 & 125,00 & 30000 & 075 & 13,00 & 130,00 & 25000 & 012* \\
\hline daily life & $\begin{array}{l}\text { Control } \\
\text { Group }\end{array}$ & 10 & 8,50 & 85,00 & 30,000 & - & 8,00 & 80,00 & 25,000 &, $012^{4}$ \\
\hline How healthy is your physical & $\begin{array}{l}\text { Research } \\
\text { Group }\end{array}$ & 10 & 11,00 & 110,00 & & & 15,50 & 155,00 & & \\
\hline environment & $\begin{array}{l}\text { Control } \\
\text { Group }\end{array}$ & 10 & 10,00 & 100,00 & $+5,000$ & (542 & 8,50 & 55,00 & - 000 &, $000^{*}$ \\
\hline Have you enough money to & $\begin{array}{l}\text { Research } \\
\text { Group }\end{array}$ & 10 & 10,00 & 100,00 & 15000 & 317 & 10,50 & 63,00 & 50000 & 1000 \\
\hline meet your needs & $\begin{array}{l}\text { Control } \\
\text { Group }\end{array}$ & 10 & 11,00 & 110,00 & 45,000 & ד17, & 10,50 & 63,00 & 30,000 & 1,000 \\
\hline $\begin{array}{l}\text { How available to you is the } \\
\text { information that you need in }\end{array}$ & $\begin{array}{l}\text { Research } \\
\text { Group }\end{array}$ & 10 & 10,50 & 105,00 & 50.000 & 1,00 & 14,75 & 105,00 & 7.500 & $.001 *$ \\
\hline your day-to-day life & $\begin{array}{l}\text { Control } \\
\text { Group }\end{array}$ & 10 & 10,50 & 105,00 & & 0 & 6,25 & 105,00 & & \\
\hline To what extent do you have & $\begin{array}{l}\text { Research } \\
\text { Group }\end{array}$ & 10 & 10,50 & 105,00 & 50000 & 1,00 & 15,50 & 155,00 & 000 & $0 \cap 0 *$ \\
\hline activities & $\begin{array}{l}\text { Control } \\
\text { Group }\end{array}$ & 10 & 10,50 & 105,00 & 30,000 & 0 & 5,50 & 147,50 & , & , \\
\hline How satisfied are you with the & $\begin{array}{l}\text { Research } \\
\text { Group }\end{array}$ & 10 & 10,50 & 105,00 & DIt & 1,00 & 10,00 & 62,50 & $500+2$ & $31+>$ \\
\hline conditions of your living place & $\begin{array}{l}\text { Control } \\
\text { Group }\end{array}$ & 10 & 10,50 & 105,00 & 0,00 & 0 & 10,00 & 62,50 & $J, 000$ & , 311 \\
\hline How satisfied are you with & $\begin{array}{l}\text { Research } \\
\text { Group }\end{array}$ & 10 & 10,50 & 105,00 & 50000 & 1,00 & 12,50 & 155,00 & 45000 & 317 \\
\hline your access to health services & $\begin{array}{l}\text { Control } \\
\text { Group }\end{array}$ & 10 & 10,50 & 105,00 & 0,000 & 0 & 10,50 & 55,00 & 4,000 & (31 \\
\hline
\end{tabular}

Table 12 shows that there is no significant difference in environment domain pre-test scores between the control and the application groups $(\mathrm{p}>0.05)$. Post-test scores of the groups differ in sub-items: how safe do you feel in your daily life $(\mathrm{U}=25.000, \mathrm{p}<0.05)$, how healthy is you physical life $(\mathrm{U}=0.000, \mathrm{p}<0.05)$, how available is to you that the information you need in your day-to-day life $(\mathrm{U}=7.500, \mathrm{p}<0.05)$, to what extent do you have the opportunity for leisure activities $(\mathrm{U}=0.000, \mathrm{p}<0.05)$, how satisfied are you with your transport $(\mathrm{U}=0.000, \mathrm{p}<0.05)$. 
Table 13. Results of the Wilcoxon pre and post-test of general quality of life and general health of the research group

\begin{tabular}{|c|c|c|c|c|c|c|}
\hline & & $\mathbf{N}$ & Mean Rank & Sum of Ranks & $\mathbf{Z}$ & $\mathbf{P}$ \\
\hline \multirow{3}{*}{ How do you find your quality of life } & Negatif rank & 0 & ,00 & ,00 & \multirow{3}{*}{$-2,739$} & \multirow{3}{*}{, $006 *$} \\
\hline & Pozitif rank & 9 & 5,00 & 45,00 & & \\
\hline & Equal & 1 & & & & \\
\hline \multirow{3}{*}{ How do you find your quality of life } & Negatif rank & 0 & ,00 & ,00 & \multirow{3}{*}{$-1,000$} & \multirow{3}{*}{,317 } \\
\hline & Pozitif rank & 1 & 1,00 & 1,00 & & \\
\hline & Equal & 9 & & & & \\
\hline
\end{tabular}

Table 13 shows a significant difference between the research groups in pre and post-test intragroup comparison results of "How do you view your quality of life?" subitem $(Z=-2.739, p<0.05)$. Intragroup comparison of pre and post-test results of a subitem of general health "How content are you with your life?" revealed a non-significant difference $(\mathrm{Z}=$ $-1.000, \mathrm{p}>0.05)$.

Table 14. Results of the Wilcoxon pre and post-test comparison of general quality of life and general health of the control group

\begin{tabular}{|c|c|c|c|c|c|c|}
\hline & & $\mathbf{N}$ & Mean Rank & Sum of Ranks & $\mathbf{Z}$ & $\mathbf{P}$ \\
\hline \multirow{3}{*}{ How do you find your quality of life } & Negatif rank & 3 & 2,50 & 7,50 & \multirow{3}{*}{1,000} & \multirow{3}{*}{,317 } \\
\hline & Pozitif rank & 1 & 2,50 & 2,50 & & \\
\hline & Equal & 6 & & & & \\
\hline \multirow{3}{*}{ How do you find your quality of life } & Negatif rank & 2 & 1,50 & 3,00 & \multirow{3}{*}{$-1,454$} & \multirow{3}{*}{, 157} \\
\hline & Pozitif rank & 0 & ,00 & ,00 & & \\
\hline & Equal & 8 & & & & \\
\hline
\end{tabular}

Table 14 shows that "How do you view your quality of life?" subitem $(Z=1.000 ; p>0.05)$ and "How content are you with your life" $(Z=-1.454, p>0.05)$ subitem pre and post-test results of the control group do not differ significantly.

Table 15. Results of the Wilcoxon pre and post-test comparison of physical domain of the research group

\begin{tabular}{|c|c|c|c|c|c|}
\hline Physical Domain & $\mathbf{N}$ & Mean Rank & Sum of Ranks & $\mathbf{Z}$ & $\mathbf{P}$ \\
\hline To what extent do you feel that Negatif rank & 0 &, 00 & ,00 & \multirow{3}{*}{,000 } & \multirow{3}{*}{1,000} \\
\hline physical pain prevents you from Pozitif rank & 0 &, 00 &, 00 & & \\
\hline doing what you need to do $\quad$ Equal & 10 & & & & \\
\hline How much do you need any Negatif rank & 0 & 00 & ,00 & \multirow{3}{*}{, 000} & \multirow{3}{*}{1,000} \\
\hline medical treatment to function in Pozitif rank & 0 &, 00 &, 00 & & \\
\hline $\begin{array}{ll}\text { your daily life } & \text { Equal } \\
\end{array}$ & 10 & & & & \\
\hline \multirow{3}{*}{$\begin{array}{l}\text { Do you have enough energy for } \frac{\mathrm{I}}{\mathrm{I}} \\
\text { everyday life }\end{array}$} & 0 &, 00 &, 00 & \multirow{3}{*}{$-1,454$} & \multirow{3}{*}{,157 } \\
\hline & 2 & 1,50 & 3,00 & & \\
\hline & 8 & & & & \\
\hline \multirow{3}{*}{$\begin{array}{l}\text { How well are you able to get } \frac{\text { Negatif rank }}{\text { Pozitif rank }} \\
\text { around }\end{array}$} & 0 & 00 & ,00 & \multirow{3}{*}{$-3,162$} & \multirow{3}{*}{, $002 *$} \\
\hline & 10 & 5,50 & 55,00 & & \\
\hline & 0 & & & & \\
\hline \multirow{3}{*}{\begin{tabular}{ll}
$\begin{array}{l}\text { How satisfied are you with your } \\
\text { sleep }\end{array}$ & $\begin{array}{l}\text { Negatif rank } \\
\text { Pozitif rank }\end{array}$ \\
\cline { 2 - 2 } & Equal \\
\end{tabular}} & 0 &, 00 &, 00 & \multirow{3}{*}{$-2,070$} & \multirow{3}{*}{, $038^{*}$} \\
\hline & 5 & 3,00 & 15,00 & & \\
\hline & 5 & & & & \\
\hline How satisfied are you with your Negatif rank & 0 &, 00 &, 00 & \multirow{3}{*}{$-2,789$} & \multirow{3}{*}{, $004 *$} \\
\hline ability to perform your daily Pozitif rank & 10 & 5,50 & 55,00 & & \\
\hline living activities & 0 & & & & \\
\hline \multirow{3}{*}{\begin{tabular}{ll} 
How satisfied are you with your $\begin{array}{l}\text { Negatif rank } \\
\text { capacity for work }\end{array}$ & Pozitif rank \\
\cline { 2 - 3 } & Equal
\end{tabular}} & 0 & ,00 &, 00 & \multirow{3}{*}{$-2,121$} & \multirow{3}{*}{, $003^{*}$} \\
\hline & 5 & 3,00 & 15,00 & & \\
\hline & 5 & & & & \\
\hline
\end{tabular}

Table 15 shows that pre and post-test results of the subitems "How satisfied are you with your capacity to work?" $(Z=$ $-3.162, \mathrm{p}<0.05)$, "How satisfied are you with your sleep?" $(\mathrm{Z}=-2.070 ; \mathrm{p}<0.05)$, "How satisfied are you with your ability to perform your daily activities?" $(Z=2.789, p<0.05)$, "How well are you able to get around?" $(Z=2.121, p<0.05)$ differ significantly. 
Table 16. Results of the Wilcoxon pre and post-test comparison of physical domain of the control group

\begin{tabular}{|c|c|c|c|c|c|}
\hline Physical Domain & $\mathbf{N}$ & Mean Rank & Sum of Ranks & $\mathbf{Z}$ & $\mathbf{P}$ \\
\hline \multirow{3}{*}{$\begin{array}{l}\text { To what extent do you feel that Negatif rank } \\
\text { physical pain prevents you Pozitif rank } \\
\text { from doing what you need to } \\
\text { do }\end{array}$} & 0 & ,00 &, 00 & \multirow{3}{*}{$-1,414$} & \multirow{3}{*}{, 157} \\
\hline & 2 & 1,50 & 3,00 & & \\
\hline & 8 & & & & \\
\hline \multirow{3}{*}{$\begin{array}{l}\text { How much do you need any Negatif rank } \\
\text { medical treatment to function Pozitif rank } \\
\text { in your daily life }\end{array}$} & 0 & ,00 &, 00 & \multirow{3}{*}{$-1,414$} & \multirow{3}{*}{, 157} \\
\hline & 2 & 1,50 & 3,00 & & \\
\hline & 8 & & & & \\
\hline \multirow{3}{*}{$\begin{array}{l}\text { Do you have enough energy- } \\
\text { for everyday life }\end{array}$} & 2 & 1,50 & 3,00 & \multirow{3}{*}{$-1,414$} & \multirow{3}{*}{, 157} \\
\hline & 0 &, 00 & ,00 & & \\
\hline & 8 & & & & \\
\hline \multirow{3}{*}{$\begin{array}{l}\text { How well are you able to get- } \\
\text { around }\end{array}$} & 0 &, 00 & ,00 & \multirow{3}{*}{, 000} & \multirow{3}{*}{1,000} \\
\hline & 0 & ,00 & ,00 & & \\
\hline & 10 & & & & \\
\hline \multirow{3}{*}{$\begin{array}{l}\text { How satisfied are you with- } \\
\text { your sleep }\end{array}$} & 0 & ,00 & , 00 & \multirow{3}{*}{$-1,414$} & \multirow{3}{*}{, 157} \\
\hline & 2 & 1,50 & 3,00 & & \\
\hline & 8 & & & & \\
\hline \multirow{3}{*}{$\begin{array}{l}\text { How satisfied are you with Negatif rank } \\
\text { your ability to perform your Pozitif rank } \\
\text { daily living activities }\end{array}$} & 0 & ,00 & ,00 & \multirow{3}{*}{$-1,414$} & \multirow{3}{*}{, 157} \\
\hline & 2 & 1,50 & 3,00 & & \\
\hline & 8 & & & & \\
\hline \multirow{3}{*}{$\begin{array}{l}\text { How satisfied are you with } \frac{\text { Negatif rank }}{\text { Pozitif rank }} \\
\text { your capacity for work }\end{array}$} & 0 & ,00 & ,00 & \multirow{3}{*}{$-1,414$} & \multirow{3}{*}{, 157} \\
\hline & 2 & 1,50 & 3,00 & & \\
\hline & 8 & & & & \\
\hline
\end{tabular}

Table 16 shows that there is non significant difference between the pre and post-test results of the subitems in the physical domain for the control group $(\mathrm{p}>0.05)$.

Table 17. Results of the Wilcoxon pre and post-test comparison of psychological domain of the research group

\begin{tabular}{|c|c|c|c|c|c|c|}
\hline Psychological Domain & & $\mathbf{N}$ & Mean Rank & Sum of Ranks & $\mathbf{Z}$ & $\mathbf{P}$ \\
\hline \multirow{3}{*}{ How much do you enjoy life } & Negatif rank & 0 & ,00 & ,00 & \multirow{3}{*}{$-2,879$} & \multirow{3}{*}{, $004 *$} \\
\hline & Pozitif rank & 2 & 1,50 & 3,00 & & \\
\hline & Equal & 8 & & & & \\
\hline \multirow{3}{*}{$\begin{array}{l}\text { To what extent do you feel your life } \\
\text { to be meaningful }\end{array}$} & Negatif rank & 0 & 00 & ,00 & \multirow{3}{*}{$-2,000$} & \multirow{3}{*}{, $046^{*}$} \\
\hline & Pozitif rank & 2 & 1,50 & 3,00 & & \\
\hline & Equal & 8 & & & & \\
\hline \multirow{3}{*}{$\begin{array}{l}\text { How well are you able to } \\
\text { concentrate }\end{array}$} & Negatif rank & 2 & 1,50 & 3,00 & \multirow{3}{*}{$-2,449$} & \multirow{3}{*}{, $014 *$} \\
\hline & Pozitif rank & 0 &, 00 &, 00 & & \\
\hline & Equal & 8 & & & & \\
\hline \multirow{3}{*}{$\begin{array}{l}\text { Are you able to accept your bodily } \\
\text { appearance }\end{array}$} & Negatif rank & 0 &, 00 & 00 & \multirow{3}{*}{, 000} & \multirow{3}{*}{1,000} \\
\hline & Pozitif rank & 0 & , 00 &, 00 & & \\
\hline & Equal & 10 & & & & \\
\hline \multirow{3}{*}{ How satisfied are you with yourself } & Negatif rank & 0 & ,00 & ,00 & \multirow{3}{*}{$-2,428$} & \multirow{3}{*}{, $015^{*}$} \\
\hline & Pozitif rank & 2 & 1,50 & 3,00 & & \\
\hline & Equal & 8 & & & & \\
\hline \multirow{3}{*}{$\begin{array}{l}\text { How often do you have negative } \\
\text { feelings such as blue mood, } \\
\text { despair, anxiety, depression }\end{array}$} & Negatif rank & 0 &, 00 &, 00 & \multirow{3}{*}{,- 564} & \multirow{3}{*}{, 564} \\
\hline & Pozitif rank & 2 & 1,50 & 3,00 & & \\
\hline & Equal & 8 & & & & \\
\hline
\end{tabular}


Table 17 shows that intragroup pre and post-test results of "To what extent do you find your life meaningful?" $(Z=$ $-2.000, p<0.05)$, "How much do you enjoy life?" $(Z=-2.879, p<0.05)$, "How satisfied are you with yourself"' $Z=-2.428$, $\mathrm{p}<0.05)$ subitems differ significantly.

Table 18. Results of the Wilcoxon pre and post-test comparison of psychological domain of the control group

\begin{tabular}{|c|c|c|c|c|c|c|}
\hline Psychological Domain & & $\mathbf{N}$ & Mean Rank & Sum of Ranks & $\mathbf{Z}$ & $\mathbf{P}$ \\
\hline \multirow{3}{*}{ How much do you enjoy life } & Negatif rank & 3 & 3,33 & 10,00 & \multirow{3}{*}{,- 707} & \multirow{3}{*}{,480 } \\
\hline & Pozitif rank & 2 & 2,50 & 5,00 & & \\
\hline & Equal & 5 & & & & \\
\hline \multirow{3}{*}{$\begin{array}{l}\text { To what extent do you feel your } \\
\text { life to be meaningful }\end{array}$} & Negatif rank & 1 & 1,50 & 1,50 & \multirow{3}{*}{, 000} & \multirow{3}{*}{1,000} \\
\hline & Pozitif rank & 1 & 1,50 & 1,50 & & \\
\hline & Equal & 8 & & & & \\
\hline \multirow{3}{*}{$\begin{array}{l}\text { How well are you able to } \\
\text { concentrate }\end{array}$} & Negatif rank & 1 & 2,50 & 2,50 & \multirow{3}{*}{$-1,000$} & \multirow{3}{*}{,317 } \\
\hline & Pozitif rank & 3 & 2,50 & 7,50 & & \\
\hline & Equal & 6 & & & & \\
\hline \multirow{3}{*}{$\begin{array}{l}\text { Are you able to accept your } \\
\text { bodily appearance }\end{array}$} & Negatif rank & 2 & 1,50 & 3,00 & \multirow{3}{*}{$-1,414$} & \multirow{3}{*}{, 157} \\
\hline & Pozitif rank & 0 &, 00 & 00 & & \\
\hline & Equal & 8 & & & & \\
\hline \multirow{3}{*}{$\begin{array}{l}\text { How satisfied are you with } \\
\text { yourself }\end{array}$} & Negatif rank & 1 & 1,50 & 1,50 & \multirow{3}{*}{, 000} & \multirow{3}{*}{1,000} \\
\hline & Pozitif rank & 1 & 1,50 & 1,50 & & \\
\hline & Equal & 8 & & & & \\
\hline \multirow{3}{*}{$\begin{array}{l}\text { How often do you have } \\
\text { negative feelings such as blue } \\
\text { mood, despair, anxiety, } \\
\text { depression }\end{array}$} & Negatif rank & 4 & 2,50 & 10,00 & \multirow{3}{*}{$-2,100$} & \multirow{3}{*}{, 051} \\
\hline & Pozitif rank & 0 & ,00 & ,00 & & \\
\hline & Equal & 6 & & & & \\
\hline
\end{tabular}

Table 18 shows that there is no significant difference between intragroup pre and post-test results of the subitems belonging to pyschological domain $(\mathrm{p}>0.05)$.

Table 19. Results of the Wilcoxon pre and post-test comparison of social domain of the research group

\begin{tabular}{|c|c|c|c|c|c|c|}
\hline Social Domain & & $\mathbf{N}$ & Mean Rank & Sum of Ranks & $\mathbf{Z}$ & $\mathbf{P}$ \\
\hline \multirow{3}{*}{$\begin{array}{l}\text { How satisfied are you with your } \\
\text { personal relationships }\end{array}$} & Negatif rank & 0 & ,00 & ,00 & \multirow{3}{*}{$-3,051$} & \multirow{3}{*}{, $002 *$} \\
\hline & Pozitif rank & 10 & 5,50 & 55,00 & & \\
\hline & $\overline{\text { Equal }}$ & 0 & & & & \\
\hline \multirow{3}{*}{$\begin{array}{l}\text { How satisfied are you with your sex } \\
\text { life }\end{array}$} & Negatif rank & 1 & 1,50 & 1,50 & \multirow{3}{*}{, 000} & \multirow{3}{*}{1,000} \\
\hline & Pozitif rank & 1 & 1,50 & 1,50 & & \\
\hline & Equal & 8 & & & & \\
\hline \multirow{3}{*}{$\begin{array}{l}\text { How satisfied are you with the } \\
\text { support you get from your friends }\end{array}$} & Negatif rank & 0 & ,00 & ,00 & \multirow{3}{*}{$-3,162$} & \multirow{3}{*}{, $002 *$} \\
\hline & Pozitif rank & 10 & 5,50 & 55,00 & & \\
\hline & Equal & 0 & & & & \\
\hline
\end{tabular}

Table 19 shows that intragroup pre and post-test results of the subitems "How satisfied are you with your personal relationships?" $(Z=-2.879, p<0.05)$ and "How satisfied are you with the support you get from your friends?" $(Z=-2.879$, $\mathrm{p}<0.05)$ differ significantly. 
Table 20. Results of the Wilcoxon pre and post-test comparison of social domain of the control group

\begin{tabular}{|c|c|c|c|c|c|c|}
\hline Social Domain & & $\mathbf{N}$ & Mean Rank & Sum of Ranks & $\mathbf{Z}$ & $\mathbf{P}$ \\
\hline \multirow{3}{*}{$\begin{array}{l}\text { How satisfied are you with your } \\
\text { personal relationships }\end{array}$} & Negatif rank & 0 & ,00 & ,00 & \multirow{3}{*}{$-1,000$} & \multirow{3}{*}{,317 } \\
\hline & Pozitif rank & 1 & 1,00 & 1,00 & & \\
\hline & Equal & 9 & & & & \\
\hline \multirow{3}{*}{$\begin{array}{l}\text { How satisfied are you with your sex } \\
\text { life }\end{array}$} & Negatif rank & 2 & 2,50 & 5,00 & \multirow{3}{*}{, 000} & \multirow{3}{*}{1,000} \\
\hline & Pozitif rank & 2 & 2,50 & 5,00 & & \\
\hline & Equal & 6 & & & & \\
\hline \multirow{3}{*}{$\begin{array}{l}\text { How satisfied are you with the } \\
\text { support you get from your friends }\end{array}$} & Negatif rank & 2 & 1,50 & 3,00 & \multirow{3}{*}{$-1,414$} & \multirow{3}{*}{, 157 } \\
\hline & Pozitif rank & 0 & ,00 & ,00 & & \\
\hline & Equal & 8 & & & & \\
\hline
\end{tabular}

Table 20 shows that there is no significant difference between intragroup pre and post-test results of the subitems belonging to social domain ( $\mathrm{p}>0.05)$.

Table 21. Results of the Wilcoxon pre and post-test comparison of environment domain of the research group

\begin{tabular}{|c|c|c|c|c|c|c|}
\hline Environment Domain & & $\mathbf{N}$ & Mean Rank & Sum of Ranks & $\mathbf{Z}$ & $\mathbf{P}$ \\
\hline \multirow{3}{*}{$\begin{array}{l}\text { How safe do you feel in your } \\
\text { daily life }\end{array}$} & Negatif rank & 0 & ,00 & ,00 & \multirow{3}{*}{$-1,414$} & \multirow{3}{*}{,157 } \\
\hline & Pozitif rank & 2 & 1,50 & 3,00 & & \\
\hline & Equal & 8 & & & & \\
\hline \multirow{3}{*}{$\begin{array}{l}\text { How healthy is your physical } \\
\text { environment }\end{array}$} & Negatif rank & 0 & ,00 & ,00 & \multirow{3}{*}{$-3,051$} & \multirow{3}{*}{, $002 *$} \\
\hline & Pozitif rank & 10 & 5,50 & 55,00 & & \\
\hline & Equal & 0 & & & & \\
\hline \multirow{3}{*}{$\begin{array}{l}\text { Have you enough money to } \\
\text { meet your needs }\end{array}$} & Negatif rank & 0 & ,00 & ,00 & \multirow{3}{*}{$-1,454$} & \multirow{3}{*}{, 157 } \\
\hline & Pozitif rank & 2 & 1,50 & 3,00 & & \\
\hline & Equal & 8 & & & & \\
\hline \multirow{3}{*}{$\begin{array}{l}\text { How available to you is the } \\
\text { information that you need in } \\
\text { your day-to-day life }\end{array}$} & Negatif rank & 0 & ,00 & ,00 & \multirow{3}{*}{$-2,739$} & \multirow{3}{*}{, $006^{*}$} \\
\hline & Pozitif rank & 9 & 5,00 & 45,00 & & \\
\hline & Equal & 1 & & & & \\
\hline \multirow{3}{*}{$\begin{array}{l}\text { To what extent do you have the } \\
\text { opportunity for leisure activities }\end{array}$} & Negatif rank & 0 & ,00 & ,00 & \multirow{3}{*}{$-3,162$} & \multirow{3}{*}{, $002 *$} \\
\hline & Pozitif rank & 10 & 5,50 & 55,00 & & \\
\hline & Equal & 0 & & & & \\
\hline \multirow{3}{*}{$\begin{array}{l}\text { How satisfied are you with the } \\
\text { conditions of your living place }\end{array}$} & Negatif rank & 0 & ,00 & ,00 & \multirow{3}{*}{, 000} & \multirow{3}{*}{1,000} \\
\hline & Pozitif rank & 0 & ,00 & ,00 & & \\
\hline & Equal & 10 & & & & \\
\hline \multirow{3}{*}{$\begin{array}{l}\text { How satisfied are you with your } \\
\text { access to health services }\end{array}$} & Negatif rank & 0 & ,00 & ,00 & \multirow{3}{*}{, 000} & \multirow{3}{*}{1,000} \\
\hline & Pozitif rank & 0 & ,00 & ,00 & & \\
\hline & Equal & 10 & & & & \\
\hline
\end{tabular}

Table 21 shows that intragroup pre and post-test results of the subitems "How healthy is you physical life?" $(Z=-3.051$, $\mathrm{p}<0.05)$, “To what extent do you have the opportunity for leisure activities?" $(Z=-2.739, p<0.05)$, "How available is to you that the information you need in your day-to-day life" $(Z=-3.162, p<0.05)$, "How satisfied are you with your transport?" $(Z=-3.000, p<0.05)$ differ significantly. 
Table 22. Results of the Wilcoxon pre and post-test comparison of environment domain of the control group

\begin{tabular}{|c|c|c|c|c|c|c|}
\hline Environment Domain & & $\mathbf{N}$ & Mean Rank & Sum of Ranks & $\mathbf{Z}$ & $\mathbf{P}$ \\
\hline \multirow{3}{*}{$\begin{array}{l}\text { How safe do you feel in your } \\
\text { daily life }\end{array}$} & Negatif rank & 1 & 2,00 & 2,00 & \multirow{3}{*}{,- 577} & \multirow{3}{*}{,564 } \\
\hline & $\overline{\text { Pozitif rank }}$ & 2 & 2,00 & 4,00 & & \\
\hline & Equal & 7 & & & & \\
\hline \multirow{3}{*}{$\begin{array}{l}\text { How healthy is your physical } \\
\text { environment }\end{array}$} & Negatif rank & 0 & ,00 & ,00 & \multirow{3}{*}{, 000} & \multirow{3}{*}{1,000} \\
\hline & Pozitif rank & 0 & ,00 & ,00 & & \\
\hline & Equal & 10 & & & & \\
\hline \multirow{3}{*}{$\begin{array}{l}\text { Have you enough money to } \\
\text { meet your needs }\end{array}$} & Negatif rank & 0 & ,00 & ,00 & \multirow{3}{*}{$-1,000$} & \multirow{3}{*}{,317 } \\
\hline & Pozitif rank & 1 & 1,00 & 1,00 & & \\
\hline & Equal & 9 & & & & \\
\hline \multirow{3}{*}{$\begin{array}{l}\text { How available to you is the } \\
\text { information that you need in } \\
\text { your day-to-day life }\end{array}$} & Negatif rank & 0 & ,00 & ,00 & \multirow{3}{*}{$-1,000$} & \multirow{3}{*}{,317 } \\
\hline & Pozitif rank & 1 & 1,00 & 1,00 & & \\
\hline & Equal & 9 & & & & \\
\hline \multirow{3}{*}{$\begin{array}{l}\text { To what extent do you have the } \\
\text { opportunity for leisure activities }\end{array}$} & Negatif rank & 0 & ,00 & ,00 & \multirow{3}{*}{$-1,414$} & \multirow{3}{*}{,157 } \\
\hline & Pozitif rank & 2 & 1,50 & 3,00 & & \\
\hline & Equal & 8 & & & & \\
\hline \multirow{3}{*}{$\begin{array}{l}\text { How satisfied are you with the } \\
\text { conditions of your living place }\end{array}$} & Negatif rank & 1 & 1,00 & 1,00 & \multirow{3}{*}{$-1,000$} & \multirow{3}{*}{,317 } \\
\hline & Pozitif rank & 0 & ,00 & 00 & & \\
\hline & Equal & 9 & & & & \\
\hline \multirow{3}{*}{$\begin{array}{l}\text { How satisfied are you with your } \\
\text { access to health services }\end{array}$} & Negatif rank & 1 & 1,00 & 1,00 & \multirow{3}{*}{$-1,000$} & \multirow{3}{*}{,317 } \\
\hline & Pozitif rank & 0 & ,00 & ,00 & & \\
\hline & Equal & 9 & & & & \\
\hline
\end{tabular}

Table 22 shows that there is no significant difference between intragroup pre and post-test results of the subitems belonging to environment domain ( $p>0.05$ ).

\section{Discussion and Conclusion}

Results of the study with the aim of determining the effects of recreational and sportive activities on quality of life of mothers with autistic children show that both groups of participants are demographically similar (Table 1-7). Half of the families in the research group have two children. It can be concluded from this that the mothers have a very high workload and can't find time for themselves. Özmen and Çetinkaya (2012) stated that families with disabled children have certain limitations in their family life due to their children's condition. $75 \%$ of the families in the research group live on the minimum wage. This income is spent on the needs of the children and the parents and it can be concluded that families can't have the possibility to take a vacation. The fact that the participants are similar can provide a clear view of the results of the study. In their research, Özmen and Çetinkaya (2012) said that incomes of the parents with disabled children don't cover their expenses. Studies also show that families that receive financial support and do not experience economic difficulties feel safer and are less affected by psychological and social problems (Deveci \& Ahmetoğlu, 2008).

Table 8 shows that there is a significant difference in quality of life and general health post-test results of the mothers in the application and the control groups $(\mathrm{p}<0.05)$ and this difference is in favor of the mothers in the application group. The statistically significant difference observed after the application is due to recreative and sportive activities that the mothers in the application group attended over the course of the study made them feel better and this is reflected in their quality of life and general health.

Table 9 shows that there is a significant difference in being content with the ability to get around, to perform daily activities, and in sleep, capacity to work between the research and the control group. This can be attributed to the fact that during the study professionals have accompanied the mothers to help them with the care of the children, therefore mothers didn't have to spend all of their time for their children and had time for resting and for themselves. A study conducted by Doğan (2001) realized that mothers carry the bigger load in the care of the disabled children, they can 
completely devote themselves to the children and this prevents them to take sometime to themselves and sometimes causes conflicts between the spouses (As cited in, Kaytez et al., 2015). It was observed that families with disabled children can't visit their neighbors when they want to, can't have social relationships, and even if they can they can only do in limited time and the only way for them to maintain social relationships is by taking their children with them wherever they go. This restricts the social attendance of the family and the family members and have a negative effect on their lives (Genç, 2017). Various researches revealed that the main criteria that determine the quality of life of families are health, resting and entertainment activities (As cited in, Canarslan, 2014).

Table 10 shows that in the psychological domain there is a significant difference between the control and the research groups in the ability to enjoy life, find a meaning in life, gather attention and in being content with oneself. Especially mothers state that they have to spend almost all of their time with their children and since the children are taking special education, they have to go to school with their children and stay in school during the education and thus cannot maintain an orderly life and face social alienation (Genç, 2017).

Table 11 shows that the research and the control group significantly differ in being satisfied with social relationships and with the support they receive from their friends in the social domain. Activities that these families can partake with their children should be provided (Genç, 2017).

Table 12 shows that the research and the control groups have significant differences in social domain post-test result sub-items: feeling safe in daily life, having a healthy physical environment, being able to reach necessary information in daily life, having time for leisure activities, being content with transport. It can be said, the fact that mothers did not have to spend all of their for their children, they were transported to wherever they wanted to go with private vehicles, they were given information about visited places and upcoming activities, and were given a chance to spend time for themselves have contributed to the observed change in the research group. Coşkun (2005) showed in his study that mothers did not differ in their quality of life according to where they live, however fathers living in villages and towns differ significantly in their quality of sleep and sexual functions (As cited in, Canarslan, 2014).

Table 13 shows that pre and post-test results of the research group for "How do you view your quality of life?" item are significantly different. It can be said that the activities they attended during the study is the reason behind this. They were able to better express themselves and have better use of their times in the activities and this might have had a better effect on their quality of life. Since there was no difference in "How content are you with your health?" item between pre and post-test reason, we can say that this short programme did not have any effect on participant's general heath.

Table 14 shows that there is no significant difference between intra-group pre and post-test results of "How do you view you quality of life?" and "How content are you with your health?" items of the control group. It can be said that, as long as their routine stays the same and they don't receive support these mothers will not experience a positive change in their quality of life.

Table 15 shows that physical domain items "How satisfied are you with your capacity to work?", "How satisfied are you with your ability to perform your daily activities?", "How satisfied are you with your sleep?", "How well are you able to get around?" intra-group pre and post-result comparison of the research group are significantly different and this can be attributed as a positive effect of the activities during the research.

Table 16 shows that the control group does not differ in intra-group comparison of pre and post-test results of physical domain sub-items. It can be said that high work load of these mothers can be tiresome and manifest as a physical fatigue. By giving higher priority to their children's needs, parents are trying to avoid guilt and find peace (Ciğerli and et al., 2014).

Table 17 shows that there is a significant difference in the intra-group comparison of the pre and post-test results of the research group psychological domain subitems: "How much do you enjoy life?", "To what extent do you find your life meaningful?", "How well are you able to concentrate?", "How satisfied are you with yourself" and this can be attributed as a positive effect of the activities.

Table 18 shows intra-group comparison of pre and post-test results of the control group psychological sub-items reveals a non-significant difference. Caring for the children and the high workload might cause a mental depression in these mothers.

Table 19 shows that there is a significant difference in the intra-group comparison of the pre and post-test results of the research group social domain subitems: "How satisfied are you with your personal relationships?", "How satisfied are you with the support you get from your friends ?" can be attributed as a positive effect of the activities they attended. It can be said that there is a need for researching the interaction of both mothers and fathers with their children with autism and an intervention program related to this (Oğuz \& Sönmez, 2017). 
Table 20 shows intra-group comparison of pre and post-test results of the control group social sub-items reveals a non-significant difference. This can be due the fact that mothers can't spare time for themselves and social activities.

Table 21 shows that there is a significant difference in the intra-group comparison of the pre and post-test results of the research group environmental domain subitems: "How healthy is you physical life?", "To what extent do you have the opportunity for leisure activities?", "How available is to you that the information you need in your day-to-day life", "How satisfied are you with your transport?" and this can be attributed as a positive effect of the activities.

Table 22 shows intra-group comparison of pre and post-test results of the control group environmental sub-items reveals a non-significant difference.

\section{Result}

Consequently, reactive and sportive activities had a positive effect on the physical, psychological, social and general quality of life of the mothers with autistic children. It was observed that both mothers and children had plenty of time to have fun and spare for themselves and enjoyed this situation.

It was observed that support programs such as these, when created and executed by professionals, can have positive results. When qualified help was offered to mothers with autistic children, their lives changed for the better.

\section{Suggestions}

It is important for the success of the support programs that they are created and executed by professionals. A similar study can be conducted with a larger sample size or a longer study duration. Number of activities that enable the families with disabled children to spend time in social environments can be increased.

\section{References}

Aydın, D., \& Ezgi, Ö. Z. (2018). Autism spectrum disorder in children and the role of the nurse in early diagnosis. Gümüşhane Üniversity Journal of Health Sciences, GÜSBD, 7(3), 93-101.

Çam, O., \& Özkan, Ö. (2009). Examination of the quality of life of families with autistic children. 12, 6(2).

Canarslan, H. (2014). Examination of the quality of life of families with disabled children. T.C. Trakya Üniversity, Institute of Social Sciences, Department of Elementary Education, Primary School Education, Master's Thesis, Edirne, 21-159.

Ciğerli, Ö., Topsever, P., Alvur, T. M., \& Görpelioğlu, S. (2014). Parental experiences of parents with disabilities from the time of diagnosis: Acceptance of Diversity. Turkish Journal of Family Medicine and Primary Care, 8(3), September, 2014, 76. https://doi.org/10.5455/tjfmpc.159761

Demir, S. A., \& Keskin, G. (2018). Difficulties faced by mothers with mentally retarded children - a qualitative study. The Journal of Academic Social Science Studies, 66, 357-372, Spring II 2018, 358.

Deveci, M., \& Ahmetoğlu, E. (2018). Investigation of perceived social support level of families with mentally retarded children. Balkan and Near Eastern Journal of Social Sciences, 04(02), 123-131.

Eser, E., Fidaner, H., Fidaner, C., Eser, S. Y., Elbi, H., \& Göker, E. (1999). WHOQOL-100 ve WHOQOL-BREEF'in Psychometric Properties. 3P Dergisi, 7(2), 23-40.

Garrett, J. R. (2014). Factors related to quality of life in families of children with autism spectrum disorder. Submitted to the Graduate School of Wayne State University Dissertations, Detroit, Michigan, 92.

Genç, Y. (2017). Anxiety levels of families with disabled children. (Sakarya Örneği) 3 nd International Congress on Political, Economic and Social Studies (ICPESS), 09-11 Nov. 2017, 248-249.

Greespan, S., \& Wieder, S. (2017). In-game treatment in autism. Özgür Publications First Edition, Isbn: 978-975-447-347-6, Translation: Müjde Işı1k Koç, 2017.

Harnois, C. (2016). Treating patients with autism spectrum Disorder. Journal of the american society of radiologic technologists, 25(1), Spring 2016.

Kaytez, N., Durualp, E., \& Kadan, G. (2015). Examining the needs and stress levels of families with disabled children. Journal of Research in Education and Teaching Şubat. 4(1), ISSN: 2146-9199, 197-214.

Kılıç, E. Ö. (2013). Autism awareness in scientific, social and legal aspects. Tübitak Journal of Science and Technology, Nisan 2013.

McStay, R. L., \& Trembath, D. (2014). Stress and family quality of life in parents of children with autism spectrum disorder: Parent Gender and the Double ABCX Model. Journal of Autism and Developmental Disorders · July https://doi.org/10.1007/s10803-014-2178-7 
Meral, B. F., \& Cavkaytar, A. (2014). Family life quality perceptions of children with autism. K. Ü. Kastamonu Journal of Education, 23(3), 1363-1380.

Oğuz, H., \& Sönmez, N. (2017). Investigation of mother-child and father-child interactions in families with children with autism spectrum disorder. Ankara University Faculty of Educational Sciences Special Education Journal, Electronic Publishing. https://doi.org/10.21565/ozelegitimdergisi.300013

Özmen, D., \& Çetinkaya, A. (2012). Problems with families with disabled children. Ege University, Journal of Nursing Faculty, 28(3), 35-49.

Top, F. Ü. (2009). Evaluation of the problems and mental status of families with autistic children: Qualitative Research. Children's Journal, 9(1), 34-42.

Uz, S., \& Kaya, K. (2018). Otizmli çocuklara ve ailelerine yönelik damgalama. Journal of History Culture and Art Research, https://doi.org/10.7596/taksad.v7i1.1411

\section{Copyrights}

Copyright for this article is retained by the author(s), with first publication rights granted to the journal.

This is an open-access article distributed under the terms and conditions of the Creative Commons Attribution license which permits unrestricted use, distribution, and reproduction in any medium, provided the original work is properly cited. 